\title{
AGRIBUSINESS CHALLENGES TO EFFECTIVENESS OF CONTRACT FARMING IN COMMERCIALIZATION OF SMALL-SCALE VEGETABLE FARMERS IN EASTERN CAPE, SOUTH AFRICA
}

\author{
Musa Khapayi ${ }^{\bowtie}$, Pieter Van Niekerk, Phillip Retief Celliers \\ Nelson Mandela University, Port Elizabeth, South Africa
}

\begin{abstract}
The study investigated the key factors that influence small-scale vegetable farmers' participation in contract farming arrangements. A sample of 70 small-scale vegetable farmers and 15 key informants of agribusiness firms involved in contract farming production of vegetables were selected in Amathole and Sarah Baartman (formerly Cacadu) district municipalities in the Eastern Cape province of South Africa. Focus group discussions and in-depth interviews were chosen as data collection tools to identify the factors that influence small-scale vegetable farmers' participation in contract farming arrangements with agribusiness firms. The data was analyzed using open multi-stage coding with an inductive framework approach. Atlas.ti was used to sort and organize data. The findings indicated availability of farm assets, hydrological conditions, farming skills and distance of producer to the markets as key determinants of contract farming participation. The use of unmarketable cultivars, inappropriate agricultural practices and inconsistent supply in quality and quantity of vegetables were found to be bottlenecks to contract participation. The study recommends a more meaningful state support and incentives for agribusiness firms; otherwise, growth of small-scale farmers in contract farming is unlikely because of the financial implications for private sector companies.
\end{abstract}

Keywords: agribusiness, commercialization, contract farming, small-scale vegetable

\section{INTRODUCTION}

Agriculture continues to be a strategic sector in the development of most low-income nations where smallscale agriculture is the dominant livelihood activity (Gani and Hossain, 2015). Currently, governments in developing countries consider the intensification of production and commercialization of small-scale farmers as a focal point in the development of subsistence agriculture and rural development (Gani and Hossain, 2015). However, the commercialization of small-scale farmers' production and enhancing their integration into lucrative markets and more inclusive value chains remain a challenge for the majority of governments in Sub-Saharan Africa (Ha et al., 2015). Commercialization of small-scale agriculture has been a difficult task owing to inappropriate policies, insufficient access to technology, poor infrastructure and institutional obstacles (Mor and Sharma, 2012).

Agribusiness value chains have been increasingly promoted by governments in Sub-Saharan Africa as one of the development strategies for enhancing growth in the agricultural sector and reduce rural poverty (Ha et al., 2015). Linking small-scale farmers into agribusiness value chains through contract farming is one of the rural development strategies being promoted to address the challenges faced by small-scale farmers (Ha et al.,

\footnotetext{
$\bowtie$ PhD Musa Khapayi, Department of Agriculture and Game Management, Nelson Mandela University, Port Elizabeth, South Africa, e-mail: musa.khapayi@mandela.ac.za, https://orcid.org/0000-0002-5839-7587
} 
Khapayi, M., van Niekerk, P., Celliers, P. R. (2018). Agribusiness challenges to effectiveness of contract farming in commercialization of small-scale vegetable farmers in Eastern Cape, South Africa. J. Agribus. Rural Dev., 4(50), 375-384. http://dx.doi. org/10.17306/J.JARD.2018.00429

2015). The topic has given rise to a body of literature analyzing various aspects of the phenomenon. However, the factors enhancing the participation of small-scale farmers into agribusiness value chains through contractual arrangements remain open to debate (Sikwela and Mushunje, 2013; Jordaan, 2012). The dynamics influencing the use of contract farming arrangements in the transition to commercial farming by small-scale farmers have not been thoroughly explored (Mmbengwa et al., 2012; Sikwela and Mushunje, 2013). The majority of past studies that sought to understand the factors influencing the participation of small-scale farmers into commercial lucrative markets were carried out in response to mixed results of structural adjustment programs that were meant to provide market-driven opportunities for rapid economic growth and development, though they failed to do so (Sikwela and Mushunje, 2013).

Despite the efforts and substantial investments made and the various policies instigated to fast-track the linkages of small-scale farmers into high-value markets, the success stories of previously disadvantaged farmers successfully operating in commercial agribusiness chains are rare (Jordaan, 2012; Mmbengwa et al., 2012; Ortmann and King, 2010). The insufficient number of success stories of small-scale farmers successfully operating in commercial agribusiness chains shows that the objectives to allow small-scale farmers to improve their livelihoods through participation in commercial agribusiness chains have not yet been met (Baloyi, 2010; Jordaan, 2012). This study aims to fill the research gap by providing empirical information on Amathole and Sarah Baartmen districts' small scale vegetable farmers' involvement in contract farming arrangements and determine the key factors that influence the participation of small-scale vegetable farmers in contract farming arrangements.

\section{LITERATURE REVIEW}

Several studies have been conducted on the bottlenecks and constraints faced by small-scale farmers in their attempts to raise income by participating in agribusiness supply chains through contractual arrangements. The aim of the studies was to broaden the knowledge base on the obstacles that limit the farmers from successfully navigating the transition into commercial farming (Sikwela and Mushunje, 2013). The studies have recognized the need to integrate small-scale farmers into high-value chains (Sikwela and Mushunje, 2013). However, despite the valuable knowledge generated by these studies, there is still a remarkable scarcity of scientific information on the factors that affect the participation of smallscale farmers in high-value chains through contractual arrangements (Sikwela and Mushunje, 2013). The linkage of small-scale farmers to contractual arrangements is seen as a business solution to poverty if the mechanisms of redistribution work (Kirsten and Sartorius, 2006; Koranteng, 2010; Little and Watts, 1994; Minot, 2011; Oya, 2012).

As regards South Africa, linkages of small-scale farmers to contract farming with agribusiness firms can provide some answers to the collapse in support services, which has occurred in most African countries following structural adjustments (Koranteng, 2010; Little and Watts, 1994; Minot, 2011). Jointly, agriculture and agribusiness firms are Africa's largest economic sectors. They are among the fastest-growing sectors in Africa since the mid-1990s (World Bank, 2011). Van Schalkwyk et al. $(2009$; 2012) argue that South African agribusiness firms operate on commercially sustainable premises. These companies are well-positioned and have the necessary experience and knowledge to provide the proper support services crucial to the development of small-scale farmers. However, engaging with small-scale farmers comes at a cost to agribusiness firms (Baloyi, 2010; Louw et al., 2007; Van der Meer, 2006). Hence many agribusiness firms tend to procure their commodity or raw materials from more established large-scale farmers who, in most instances, also export their produce (Baloyi, 2010; Louw et al., 2007). This is done to ensure that the product procured meets the local as well as the international standards and to maintain low transaction costs (Baloyi, 2010; Louw et al., 2007). This trend leaves small-scale farmers marginalized and further excluded from profitable niche markets (Baloyi, 2010; Louw et al., 2007).

Owing to past South African government policies and the lack of appropriate support structures for the beneficiaries of redistributed and restituted land by the new democratic government, small-scale farmers in South Africa do not have adequate infrastructure, innovative technology or capital that is required to meet the demands of agri-processing firms, supermarket chains and the retail sector (Ayinke, 2011; Baloyi, 2010). There is a quantum difference in both the quality and quantity of commodities produced by small-scale farmers compared to commercial farmers who meet the requirements 
Khapayi, M., van Niekerk, P., Celliers, P. R. (2018). Agribusiness challenges to effectiveness of contract farming in commercialization of small-scale vegetable farmers in Eastern Cape, South Africa. J. Agribus. Rural Dev., 4(50), 375-384. http://dx.doi. org/10.17306/J.JARD.2018.00429

of the agri-processing firms, food retailers and supermarket chains (Ayinke, 2011; Baloyi, 2010; Groenewald, 2004; Gulati et al., 2007; Koranteng, 2010). These factors hold critical ramifications not only in terms of barriers to commercialization, but also in terms of the relationship between agribusiness and small-scale vegetable farmers (Ayinke, 2011; Baloyi, 2010).

\section{THEORECTICAL AND CONCEPTUAL FRAMEWORK}

\section{Theoretical framework}

This study is guided by the Social Exchange theory of sociologist George Homans (1950, 1958, 1961, 2017). According to Homans (1950, 1958, 1961, 2017), human relationships are shaped by a subjective cost-benefit analysis and a comparison of alternatives. Thibaut and Kelley (1959) argue that in order for a dyadic relationship to be viable, it must provide rewards and/or economies in costs which compare with those in other competing relationships. Thibaut and Kelley (1959) further explain that people choose relationships around them that provide the most rewards or require the least costs. Blau (1968) and (Levinger, 1979) greatly expand on the importance of the Social Exchange theory arguing that individuals enter into and maintain a relationship as long as they can satisfy their interest and at the same time ensure that the benefits outweigh the costs. According to Rwelamina (2015), cited in Rugema et al. (2018), people participate in collective action owing to their expectations such as access to services and maximization of self-interest and benefits. Therefore, the Social Exchange theory (SE) was seen appropriate for exploring the key determining factors of small-scale vegetable farmers to participate in contract farming arrangements with agribusiness firms.

\section{Conceptual framework}

Contract farming definitions are as many as the number of authors on the subject (Duma, 2007). However, despite the multiple definitions and various terms by which contract farming is known, what is referred to remains, in essence, farmers growing crops for contractors with the assistance of the contractors (Duma, 2007). The factors determining inclusion or exclusion and their impact on the broader dynamic of contract farming remain vague and inadequately addressed by earlier research. In South Africa, small-scale farmers practice subsistence farming, oriented by insufficient uses of production inputs, lack of irrigation infrastructure and being highly dependent on rain-fed conditions, which result in difficulties in increasing productivity levels. Contract farming arrangements have been reported by a number of researchers as a potential strategy to address the barriers that small-scale farmers face when migrating into commercial agricultural markets while increasing their productivity (Duma, 2007).

This study deflates this viewpoint and rekindles the debate through a critical exploration of the factors impacting the relationship between agribusiness and small-scale vegetable farmers under contract farming. This relationship - and how it is impacted by the government - forms the conceptual framework of this study. As shown in Figure 1, small-scale farmers are caught at the core of the problem, affecting their access to credit, lucrative markets and support services. Despite the current government's pro-smallholder farmer policies aimed at enhancing farmer production capabilities, small-scale farmers remain largely excluded from commercialization due to factors inhibiting their participation in the contract farming system.

\section{METHODOLOGY}

\section{Description of survey area}

The study was conducted in two districts, namely: Amathole district and Sarah Baartman (formerly Cacadu district municipality) purposively selected in the Eastern Cape Province. The Eastern Cape is one of South Africa's nine provinces (Altman et al., 2009). The province is located on the east coast of South Africa between the Western Cape and KwaZulu-Natal provinces (Altman et al., 2009). Amathole district municipality occupies the central portion of the Eastern Cape and Sarah Baartman district municipality shares border with the Western Cape and Northern Cape (Altman et al., 2009). The districts are largely rural, with low urbanization rates as well as limited budgetary capacity and municipal staff. Amongst these obstacles are high poverty rates resulting from high unemployment, low incomes and lack of basic skills that are required for local economic development (Altman et al., 2009). Many people in the district municipalities rely on agriculture, gifts, state pension and labor remittances for household survival. Contract farming has been adopted in the municipalities to grow various crops. 
Khapayi, M., van Niekerk, P., Celliers, P. R. (2018). Agribusiness challenges to effectiveness of contract farming in commercialization of small-scale vegetable farmers in Eastern Cape, South Africa. J. Agribus. Rural Dev., 4(50), 375-384. http://dx.doi. org/10.17306/J.JARD.2018.00429

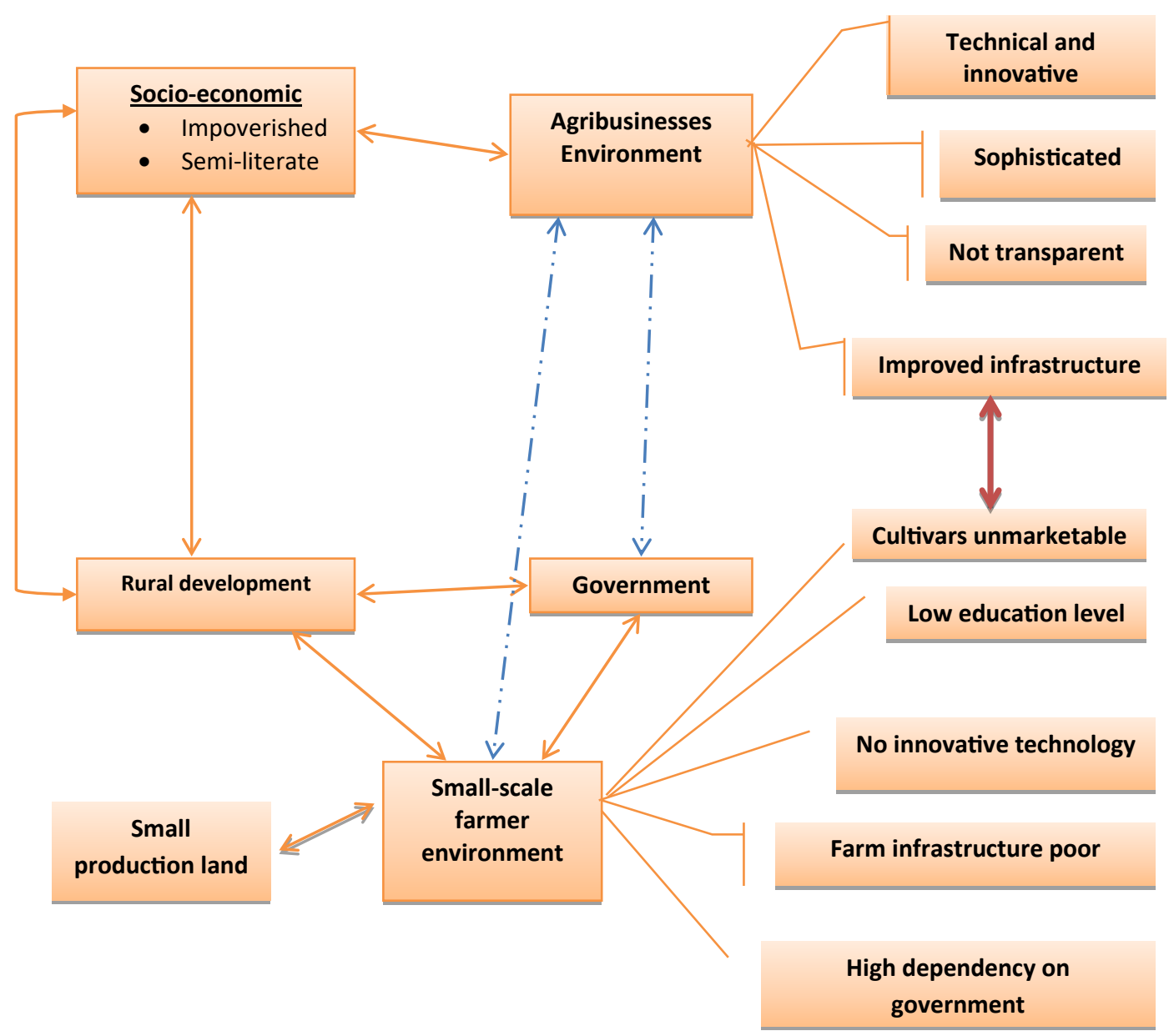

$<\cdot\rangle$

Indicates the "missing links" in contract farming to become a viable agrarian reform strategy. Central to this are agribusiness incentives from the state and adequately revised policy and practical measures; the state must provide the elements still lacking at present.

Red arrow indicates the polarized, dualistic environment and the conflict of interest that continue to characterize contract farming and the interaction between agribusiness and small-scale farmers.

Fig. 1. Agricultural dichotomy: the polarized contract farming environment Source: own elaboration based on research.

\section{Data collection}

The methodology employed in this study was a qualitative research approach. The rationale behind the use of a qualitative methodology is the descriptive nature of this approach. The use of a qualitative approach enabled the researcher to reach an in-depth analysis of the most important factors that influence small-scale vegetable farmers' participation in contract farming arrangements. In contrast to the quantitative approach which focuses on statistics and figures, the qualitative approach focuses on words of the respondents and the themes emerging from their narratives. Two qualitative 
Khapayi, M., van Niekerk, P., Celliers, P. R. (2018). Agribusiness challenges to effectiveness of contract farming in commercialization of small-scale vegetable farmers in Eastern Cape, South Africa. J. Agribus. Rural Dev., 4(50), 375-384. http://dx.doi. org/10.17306/J.JARD.2018.00429

\begin{tabular}{|c|c|c|}
\hline Study objectives & Themes emerging & Category \\
\hline Determinants of CF participation & Participation conditions & $\begin{array}{l}\text { - Farm assets } \\
\text { - Experience in agriculture } \\
\text { - Hydrological conditions } \\
\text { - Farming skills } \\
\text { - Levels of education } \\
\text { - Age } \\
\text { - Size of farm } \\
\text { - Distance of producer } \\
\text { - Land tenure }\end{array}$ \\
\hline Challenges in CF participation & Participation constraints & $\begin{array}{l}\text { - GAP norms } \\
\text { - unmarketable cultivars } \\
\text { - Lack of communication lines } \\
\text { - Inconsistent quality and quantity } \\
\text { - Trust }\end{array}$ \\
\hline
\end{tabular}

Fig. 2. Objectives, themes and categories of the study

Source: own elaboration based on research.

research techniques were applied to gather primary data, namely focus group discussions and individual indepth interviews. The combination of the two methods allowed gaining substantive insights into the studied phenomenon.

Since an accurate list of the population needed for this study was not available, it was seen as not reasonable or possible to develop a sampling frame from which a probability sample could be obtained. According to Statistics... (2011), South Africa lacks comprehensive statistical information on small-scale farmers and subsistence agriculture. Most researchers commonly rely on survey estimates derived on specific studies carried out across the country by various agricultural departments, universities and a handful of non-governmental organizations (NGOs) (Moyo, 2011; Raleting and Obi, 2015). There are no comprehensive statistics on the number of subsistence agricultural producers in South Africa (Moyo, 2011; Raleting and Obi, 2015). Thus, the total number of subsistence farmers in the survey area could not be realized from Statistics South Africa or the Department of Agriculture. After carefully considering all the weaknesses and strengths of the various types of non-probability sampling methods, it was decided to make use of the purposive (judgment) sampling procedure. Purposive sampling can be very useful when one needs to reach a targeted sample quickly and where sampling for proportionality is not the primary concern.
About 70 small-scale vegetable farmers ${ }^{1}$ and 15 key informants of agribusiness firms ${ }^{2}$ that met the criteria for inclusion in the study were purposively selected to provide a holistic view of contract farming.

The central topic for small-scale farmers' focus group discussion and individual in-depth interviews with the key informants was to gain invaluable insight on the key requirements for contractual relationships and out-grower schemes between small-scale farmers and agribusiness firms. This allowed the researcher to gain a deep insight into the conditions required by agribusiness firms to engage small-scale vegetable farmers in contractual arrangements. These discussions sought to clarify the factors that affect the participation of small-scale farmers in contract farming arrangements. It was easy to collect data from the farmers and the key informants because of their daily interaction with agribusiness firms. The participants were all African, mostly Xhosa. Therefore, all the focus group discussion took place in isiXhosa, the language spoken by the participants. All sessions were audio-taped, translated

\footnotetext{
${ }^{1}$ Small-scale farmers were involved in primary production with a farm size between 3 ha to 12 ha as per definition by Agri-bank.

${ }^{2}$ Agribusiness firms were involved in processing, value adding and marketing and sales of agricultural commodities; were operating for more than five years.
} 
and transcribed into English. Although there were seven focus groups, data saturation was reached after the $6^{\text {th }}$ group. Therefore, the researcher used point-of-data saturation in deciding on the final number of focus groups needed to collect sufficient data: the point at which no new information or themes relevant to the study emerge from each subsequent interview.

\section{Data analysis}

The study employed open multi-stage coding with an inductive framework approach to analyze the data collected. Coding allowed topics to emerge from the data by conceptualizing data and breaking it down into discrete units and organizing into categories or codes named to represent the specific phenomenon. According to Richards (2005) and Strauss and Corbin (1990), this process makes themes emerge from the data, leading to the development of theories. Codes relevant to the research question were created, themes were then established and the data was systematically examined to see the ways in which themes were portrayed. The analysis followed with organizing the data into manageable themes, patterns, trends and relationships (Mouton, 2001). According to Mouton (2001), this usually results in the identification of recurring patterns that cut through the data. The inductive analysis allowed categories and patterns to emerge from the data leading to sets of smaller and similar data units that are more workable. A comparative method was used to compare one unit of data with another looking for recurring regularities and patterns in the data in order to assign the data into categories. The developed data categories were further sub-divided to determine links between categories and to form hypotheses that lead to the development of theories. A computer-based qualitative data program Atlas.ti was used to sort and organize the data.

\section{RESULTS AND DISCUSSION}

\section{Participation conditions}

Findings from the focus group discussions and key informant interviews revealed serious reservations by agribusiness firms in engaging in contract farming programs with producers who do not have a collateral in the form of ownership of their land or who have small farms. Land is one of the most important agricultural resources, playing a fundamental role in agricultural productivity and high-value market participation by a farmer. This resource, complemented by other ones, is widely acknowledged by a number of researchers as a crucial determinant of the income-earning potential (Baloyi, 2010; Moyo, 2010). Large farms were mostly preferred by agribusiness firms when selecting vegetable contract farmers. Having a small farm increased the likelihood of a farmer being excluded from the contract farming arrangements. The respondents felt that access to a significant area of land is crucial for a farmer to be able to rotate crops and rest the soil. Resting the soil and rotating crops is difficult for farmers cultivating on small tracts of land. None of the respondents commented on the preferred size of land in hectares.

The study also revealed that access to irrigation systems played a vital role in promoting participation of small-scale vegetable farmers in contract farming arrangements. With access to irrigation systems, a farmer will be able to deliver the required quality and quantity of produce. The interviewed key agribusiness firms' informants mentioned that they assist contracted farmers with supply of water and irrigation systems by drilling boreholes and installing irrigation systems in cases were the assets are lacking and the farmer owns the land. This is done to ensure that the farmer has sufficient water supply available to produce the required quantities and quality of vegetables. When farmers do not have ownership of the land they occupy and produce from, investing in the land is problematic and risky. The availability of irrigation systems and quality irrigation water is a principal resource in agriculture, particularly in horticulture production (Baloyi, 2010; Dawe et al., 2015). Dawe et al. (2015) links the success stories of the Philippines and Indonesia in the production of rice to adequate access to high-yielding varieties and fertilizers as well as access to irrigation systems.

Younger age, literacy and related skills positively influenced participation in contract farming between small-scale vegetable farmers and agribusiness firms. The results indicated that agribusiness firms preferred to contract younger small-scale farmers that have attained higher levels of education rather than contracting with old farmers with low levels of education. Similar results were found by Duma (2007) with household head age and education levels being found to be significant predictors in contract farming programs. Baloyi (2010) and Jari (2009) argue that old age might pose a threat to the sustainability of partnership, particularly farming. This is owing to old age being the time at which most people 
lack energy, are physically weak and have poor health, which renders them unsuitable as potential farmers for contractual arrangements or obtaining loans from potential agribusiness firms, especially when no collateral is available. According to Jayne et al. (2010), education levels determine human capital levels of household and the ability to interpret agricultural information and make informed decisions.

The distance between the farm and the market was found to be amongst the most critical factors to agribusinesses in terms of engaging farmers in contract farming. Goetz (2015) found the distance from farm to market to be a critical factor in market participation when studying the selective model of household food marketing behavior in Sub-Saharan Africa. Similar results were found by Bahta and Bauer (2012) in their study of the determinants of market participation of small-scale livestock farmers in South Africa and by Omiti et al. (2009) when studying the factors influencing the intensity of market participation by small-scale farmers in the rural peri-urban areas of Kenya. Short distances from markets were mostly preferred by the agribusiness firms. According to the majority of respondents, market transaction costs are usually lower when the producer is located close to markets. Respondents indicated that the preferred distance between the agribusiness firms and the contract farmers varies in the range of $20 \mathrm{~km}$ to $35 \mathrm{~km}$. Any additional distances from the agribusiness firms' premises or their distribution centers or inability of the farmer to deliver agricultural commodities to the agribusinesses premises inhibits the chances of a farmer participating in contract farming programs.

Experience in agriculture, coupled with farming skills, was indicated by the respondents as another key determinant used to select vegetable contract farmers. Van Schalkwyk et al. (2012) argue that techniques of farming demand that the farmer possesses some degree of experience and skills in farming. The authors further argue that the lower the number of years in farming, the higher the probability that the farmer will be technically constrained. Raphela (2014) explains farming experience as thorough knowledge and understanding of the dynamics of the agricultural sector.

\section{Participation constraints}

The respondents indicated that, owing to lack of training and because small-scale farmers are risk-averse, they usually follow inappropriate agricultural practices in their production. Lack of good agricultural practices was stated to be one of the factors that deter agribusiness firms from obtaining their commodities from smallscale vegetable farmers. The Agricultural Products Standards Act (No. 119) of 1990 provides control over the sale of agricultural products, ensuring that all agricultural products procured comply with the minimum quality standards outlined and specified in the Act. The agribusinesses required contract farmers to have a good safety certification audit. The respondents agreed that small-scale farmers struggle to comply with these standards owing to lack of infrastructure and resources. With regard to disease control, the interviewees revealed that small-scale vegetable producers use domestic pesticides and herbicides owing to their low costs as compared to expensive commercial pesticides and herbicides. These products are neither accepted nor recognized under the Agricultural Products Standards Act. The use of domestic pesticides by the producers leaves more residuals on their produce, making it problematic for the product to meet the pesticides and herbicides residue requirements set by the firms and government in response to the demand of consumers and export markets.

Trust was stated to be another crucial factor in the success of contract farming arrangements between agribusiness firms and vegetable contract farmers. When choosing primary producers to contract with, the interviewees divulged that trustworthiness of producers to deliver a consistent quality and quantity of produce on time is crucial. The agribusiness firms identified that delivery and quality of small-scale producers are inconsistent, and quality and quantity of produce is not guaranteed. These shortcomings stem from a lack of planning by the farmers. When analyzing agricultural contracts with small-scale farmers in the Winterveld region in South Africa, Haggblade et al. (2012) found that trust between agribusiness firms and contract farmers plays a significant role in reducing transaction costs to the parties. According to the authors, trust between the contracting parties reduces or eliminates the costs that are associated with screening, investigating and enforcing the contracts (Haggblade et al., 2012).

The cultivation of unmarketable cultivars by smallscale farmers and lack of communication infrastructure were pointed out as being another of the challenges that limit agribusiness firms from engaging with small-scale farmers in contracts. According to the respondents, small-scale farmers are isolated and lack communication 
Khapayi, M., van Niekerk, P., Celliers, P. R. (2018). Agribusiness challenges to effectiveness of contract farming in commercialization of small-scale vegetable farmers in Eastern Cape, South Africa. J. Agribus. Rural Dev., 4(50), 375-384. http://dx.doi. org/10.17306/J.JARD.2018.00429

lines, which prevent them from obtaining any up-to-date information on commodity prices, vegetable cultivars in demand or markets changes. This contributes to a poor relationship with agribusiness firms and leaves the farmers with the perception that they have been cheated.

\section{CONCLUSIONS AND RECOMMENDATION}

Small-scale farmers find it difficult, if not impossible, to engage in contractual arrangements with agribusiness firms owing to a number of unique, substantial challenges they continue to face. A major concern about the exclusion of small-scale farmers from agribusiness value chains are the strategies used by agribusiness firms in the sourcing and procurement of their agricultural raw materials. These strategies have a negative effect on the participation of small-scale farmers in agribusiness chains by effectively excluding them. Fundamentally, these strategies are rooted in economic benefit: the bottom line for agribusiness firms is profit margins; and this very basic commercial principle is what mitigates against the effectiveness of contract farming. The basic production and infrastructural specifications of agribusiness programs put contract farming beyond the means of the majority of small-scale vegetable producers. Unless the conditions related to agribusiness are met, the divide will widen between small-scale producers and large agribusiness firms, with agribusiness firms opting to do business with a network that satisfies their requirements, while small-scale producers continue to be entrapped in the vicious cycle of poverty. A strategic overhaul of contract farming is needed but will only have a chance of success if supporting private-state mechanisms address the broad spectrum of shortcomings that bar the majority of small-scale producers from achieving commercial status. From the agribusiness perspective, the state also needs to address the high transaction costs inherent in contract farming, such as transport. Without more meaningful state support and incentives, growth of small-scale farmers in contract farming is unlikely because of the financial implications for private sector companies. Without such interventions, the conflict of interest that exists between agribusiness and small-scale farmers in the context of contract farming will continue to hamper the development potential of contract farming as well as to hinder the agrarian reform within the Eastern Cape Province.

\section{ACKNOWLEDGEMENTS}

This research was supported by the National Institute for the Humanities and Social Science.

\section{REFERENCES}

Aliber, M., Hall, R. (2012). Support for smallholder farmers in South Africa: Challenges of scale and strategy. Dev. South. Afr., 29(4), 548-562.

Altman, M., Hart, T. G., Jacobs, P. T. (2009). Household food security status in South Africa. Agrekon, 48(4), 345-361.

Ayinke, O. O. (2011). Contract farming in developing emerging farmers in South Africa: Exploring the Gledhow Mansomini sugarcane scheme. Master's dissertation. Stellenbosch: University of Stellenbosch.

Bahta, S., Bauer, S. (2012). Policy options for improving market participation and sales of smallholder crop producers: A case study of the Free State Province of South Africa. Afr. J. Agric. Res., 7(24), 3525-3533.

Baloyi, J. K. (2010). An analysis of constraints facing smallholder farmers in the agribusiness value chain: a case study of farmers in the Limpopo Province. M.Inst.Agrar. dissertation. Department of Agricultural Economics, Extension and Rural Development. Pretoria: University of Pretoria.

Blau, P. M. (1968). Social exchange. International encyclopedia of the social sciences $(7,452-457$.

Davis, J. H., Goldberg, R. A. (1957). Concept of agribusiness. Division of Research, Graduate School of Business Administration. Boston: Harvard UP.

Dawe, D., Morales-Opazo, C., Balie, J., Pierre, G. (2015). How much have domestic food prices increased in the new era of higher food prices?. Glob. Food Sec., 5, 1-10.

Duma, M. (2007). Contract farming as a tool for the development of smallholder farmers. Unpublished dissertation. Stellenbosch: University of Stellenbosch.

Gani, O., Hossain, E. (2015). Market participation decision of smallholder farmers and its determinants in Bangladesh. Ekon. Poljopriv., 62(1), 163-179.

Goetz, A. (2015). Different Regions, Different Reasons? Comparing Chinese land-consuming outward investments in Southeast Asia and Sub-Saharan Africa. Conference Paper No. 37, Land grabbing, conflict and agrarian-environmental transformations: Perspectives from East and Southeast Asia, 5-6 June 2015, Chiang Mai University.

Groenewald, J. A. (2004). Conditions for successful land reform in Africa. South African J. Econ. Manag. Sci., 7(4), 673-682.

Gulati, A., Minot, N., Delgado, C., Bora, S. (2007). Growth in high-value agriculture in Asia and the emergence of vertical 
Khapayi, M., van Niekerk, P., Celliers, P. R. (2018). Agribusiness challenges to effectiveness of contract farming in commercialization of small-scale vegetable farmers in Eastern Cape, South Africa. J. Agribus. Rural Dev., 4(50), 375-384. http://dx.doi. org/10.17306/J.JARD.2018.00429

links with farmers. Global supply chains: standards and the poor: how the globalization of food systems and standards affects rural development and poverty (pp. 98-108).

Ha, T. M., Bosch, O. J., Nguyen, N. C. (2015). Systemic interventions addressing market access challenges of smallholder vegetable farmers in Northern Vietnam. Int. J. Mark. Bus. Syst., 1(2), 136-158.

Haggblade, S., Andersson Djurfeldt, A., Banda Nyirenda, D., Bergman Lodin, J., Brimer, L., Chiona, M., Chitundu, M., Chiwona-Karltun, L., Cuambe, C., Dolislager, M., Donovan, C. (2012). Cassava commercialization in Southeastern Africa. J. Agribus. Dev. Emerg. Econ., 2(1), 4-40.

Homans, G. C. (1953). Status among clerical workers. Human Org., 12(1), 5-10.

Homans, G. C. (1958). Social behavior as exchange. Am. J. Soc., 63(6), 597-606.

Homans, G. C. (1961). Human behavior: Its elementary forms. Harcourt Brace: San Diego.

Homans, G. C. (2017). Contemporary theory in sociology. In: Sociological Methods (pp. 51-69). Routledge: London.

Jari, B. (2009). Institutional and technical factors influencing agricultural marketing channel choices amongst small holders and emerging farmers in the Kat River Valley. Doctoral thesis. Alice: University of Fort Hare.

Jayne, T. S., Mather, D., Mghenyi, E. (2010). Principal challenges con-fronting smallholder agriculture in sub-Saharan Africa. World Dev., 38(10), 1384-1398.

Jordaan, H. (2012). New Institutional Economics analysis of emerging irrigation farmers' food value chains. Ph.D. thesis. Department of Agricultural Economics. Bloemfontein: University of the Free State.

Kirsten, J. F., Sartorius, K. (2006). Contracts and contract farming as potential mechanisms to improve market access for black farmers in South Africa. University of Pretoria. Retrieved April !st 2010 from: http://www.web. up.ac.za

Koranteng, K. Y. (2010). Contract farming model of financing smallholder farmers in South Africa: The case of the IDC-Kat River citrus development scheme. Unpublished research report. Bellville: University of Stellenbosch Business School.

Levinger, G. (1979). A social exchange view on the dissolution of pair relationships. In: Social exchange in developing relationships (pp. 169-193). New York - San Francisco - London: Academic Press

Little, P. D, Watts, M. J. (Eds.). (1994). Living under contract: Contract farming and agrarian transformation in sub-Saharan Africa. Madison: University of Wisconsin Press.

Louw, A., Vermeulen, H., Kirsten, J., Madevu, H. (2007). Securing small farmer participation in supermarket supply chains in South Africa. Dev. South. Afr., 24(4), 539-551.
Minot, N. (2011). Contract Farming in Africa: Opportunities and Challenges, presented at the AAMP Policy Seminar"Successful Smallholder Commercialization", Rwanda, Kigali. Retrieved from http://fsg.afre.msu.edu/aamp/Kigali\%20Conference/Minot_Contract_farming_in_Africa. pdf

Mmbengwa, V. M., Groenewald, J. A., Van Schalkwyk, H. D., Maiwashe, A. (2012). Analysis of capacity building indicators and their influences on the viability of farming small, micro and medium enterprises (SMMEs) in South Africa. Afr. J. Bus. Manag., 6(36), 9923-9935.

Mor, S., Sharma, S. (2012). Technical efficiency and supply chain practices in dairying: The case of India. Agric. Econ. Zemedel. Ekon., 58(2).

Mouton, J. (2001). How to succeed in your master's and doctoral studies: A South African guide and resource book. Van Schaik.

Moyo, B. H. Z. (2010). The use and role of indigenous knowledge in small-scale agricultural systems in Africa: the case of farmers in northern Malawi. Doctoral thesis. Glasgow: University of Glasgow.

Moyo, S. (2011). Three decades of agrarian reform in Zimbabwe. J. Peas. Stud., 38(3), 493-531.

Nichol, J. (1997). Bioclimatic impacts of the 1994 smoke haze event in Southeast Asia. Atm. Env., 31(8), 1209-1219.

Omiti, J., Otieno, D., Nyanamba, T., McCullough, E. (2009). Factors influencing the intensity of market participation by smallholder farmers: A case study of rural and peri-urban areas of Kenya. Afr. J. Agric. Res. Econ., 3(1), 57-82.

Ortmann, G. F., King, R. P. (2010). Research on agri-food supply chains in Southern Africa involving small-scale farmers: Current status and future possibilities. Agrekon, 49(4), 397-417.

Oya, C. (2012). Contract farming in Sub-Saharan Africa: A survey of approaches, debates and issues. J. Agrar. Change, 12(1), 1-33.

Pingali, P. L. (1997). From subsistence to commercial production systems: The transformation of Asian agriculture. Am. J. Agric. Econ., 79(2), 628-634.

Poulton, C., Macartney, J. (2012). Can public-private partnerships leverage private investment in agricultural value chains in Africa? A preliminary review. World Dev., 40(1), 96-109.

Raleting, P. M., Obi, A. (2015). An analysis of institutional factors Influencing vegetable production amongst smallscale farmers in six vegetable projects of the Nkonkobe Local Municipality. J. Agric. Sci., 7(6), 184-196.

Raphela, M. G. M. (2014). Smallholder farmers in Ekurhuleni: the challenges and constraints of access to agricultural markets. Doctoral dissertation. Stellenbosch: Stellenbosch University. 
Khapayi, M., van Niekerk, P., Celliers, P. R. (2018). Agribusiness challenges to effectiveness of contract farming in commercialization of small-scale vegetable farmers in Eastern Cape, South Africa. J. Agribus. Rural Dev., 4(50), 375-384. http://dx.doi. org/10.17306/J.JARD.2018.00429

Richards, M. A. (2005). Fundamentals of radar signal processing. Tata McGraw-Hill Education.

Rugema, S. H., Sseguya, H., Kibwika, P. (2018). Determinants of smallholder farmers' participation in rice value chains in Uganda. J. Agric. Exten., 22(2), 62-71.

Rwelamira, J. (2015). Strengthening farmers organizations and civil society organizations. Sasakawa Africa Association. Retrieved at November $20^{\text {th }} 2018$ from: https://www. afdb.org/fileadmin/uploads/afdb/Documents/Events/DakAgri2015/Strengthening_Farmers_Organizations_and Civil_Society_Organizations.pdf

Sikwela, M. M., Mushunje, A. (2013). The impact of farmer support programmes on household income and sustainability in smallholder production: A case study of the Eastern Cape and KwaZulu-Natal farmers, South Africa. Afr. J. Agric. Res., 8(21), 2502-2511.

Staatz, J. (2011). Enhancing agricultural productivity. Agribusiness for Africa's prosperity. Vienna: United Nations Industrial Development Organization (UNIDO).

Statistics South Africa (2011). General household survey 2012. Pretoria: Statistics South Africa.

Strauss, A., Corbin, J. (1990). Basics of qualitative research: Grounded theory, procedures and techniques Newbury Park, CA: Sage publications.
Thibaut, J. W., Kelley, H. H. (1959). The social psychology of groups New York: Wiley.

Van der Meer, C. (2006). Exclusion of small-scale farmers from coordinated supply chains. In: R. Ruben, M. Slingerland, H. Nijhoff (Eds.), The Agro-Food Chains and Networks for Development. Dordrecht: Springer.

Van Schalkwyk, H. D., Carstens, J. P., Cloete, P. C., Van Der Merwe, J. D. (2009). Master plan for agriculture in the North West Province. Mafikeng: North West Dept of Agriculture, Conservation, Environment and Rural Development.

Van Schalkwyk, H. D., Groenewald, J. A, Fraser, G. C. G, Obi, A., Van Tilburg, A. (2012). Unlocking markets to smallholders: Lessons from South Africa. Mansholt Publication series, 10. The Netherlands.

World Bank (2011). Cultivating knowledge and skills to grow African agriculture: A synthesis of institutional, regional and international review. Washington: Agriculture and Rural Development Department, Africa Region: Human Dept. 